\title{
Interferon Gamma Drastically Modifies the Regulation of Interleukin 1 Genes by Endotoxin in U937 Cells
}

\author{
C. Ucla, ${ }^{\star}$ P. Roux-Lombard, ${ }^{\ddagger}$ S. Fey, ${ }^{\star}$ J.-M. Dayer, ${ }^{\ddagger}$ and B. Mach* \\ ${ }^{*}$ Department of Microbiology and ${ }^{\ddagger}$ Division of Immunology and Allergy, University of Geneva Medical School, Geneva, Switzerland
}

\begin{abstract}
IL-1 $\alpha$, IL-1 $\beta$, and tumor necrosis factor $\alpha$ (TNF- $\alpha)$ gene expression is induced by LPS (endotoxin) in monocytes/macrophages and in some monocytic cell lines. IFN $\gamma$ and $1 \alpha, 25-\mathrm{di}-$ hydroxyvitamin $D_{3}\left(1,25[\mathrm{OH}]_{2} \mathrm{D}_{3}\right)$ are important macrophageactivating factors. They induce changes in the human monocyte cell line U937 that reflect cellular differentiation. We have studied the effect of IFN- $\gamma$ and of $1,25(\mathrm{OH})_{2} \mathrm{D}_{3}$ on the expression of IL-1 and TNF- $\alpha$ messenger RNA in response to LPS. The induction of these genes by LPS is immediate and transient, with a maximum in $3 \mathrm{~h}$. Preincubation of the cells with IFN- $\gamma$ or with $1,25(\mathrm{OH})_{2} D_{3}$ increases these mRNA responses to LPS about fourfold.

More importantly, cells exposed to IFN- $\gamma$ for 72 h exhibit a drastically different and unexpected pattern of $I L-1 \alpha$ and IL-1 $\beta$ gene response to LPS. Instead of the normal transient response, one then observes a sustained increase in IL-1 $\alpha$ and IL-1 $\beta$ gene expression over at least $16 \mathrm{~h}$ after LPS stimulation. This was measured both at the level of mRNA and by direct transcription assays (run-off). This striking effect of IFN- $\gamma$ on the kinetics of IL-1 gene response does not apply to the TNF- $\alpha$ gene. Interestingly, $1,25(\mathrm{OH})_{2} \mathrm{D}_{3}$, which shares with IFN- $\gamma$ a number of important effects on monocytes/macrophages, does not affect the kinetics of IL-1 gene response to LPS. In view of the biological relevance of endotoxin as a macrophage activator, the potential clinical implication of this prolonged induction of IL-1 gene expression is discussed. (J. Clin. Invest. 1990. 85:185-191.) endotoxin • gene regulation • interferon $\gamma \bullet$ interleukin 1
\end{abstract}

\section{Introduction}

Several distinct signals are capable of activating monocytes/ macrophages to express new phenotypic markers such as specific enzymes and surface antigens or to secrete specific cytokines $(1,2)$. Distinct macrophage activation programs can be recognized. For instance, endotoxin activates the IL-1 and tumor necrosis factor $\alpha$ (TNF- $\alpha)^{1}$ genes, resulting in an increase in the production of these cytokines $(2,3)$, while IFN- $\gamma$

Address reprint requests to Dr. B. Mach, Department of Microbiology, University of Geneva Medical School, CMU, 9 Avenue De Champel, 1211 Geneva, Switzerland.

Received for publication 10 February 1989 and in revised form 20 June 1989.

1. Abbreviations used in this paper: $1 \alpha, 25$-dihydroxyvitamin $\mathrm{D}_{3}$, $1,25(\mathrm{OH})_{2} \mathrm{D}_{3} ; \mathrm{TNF}-\alpha$, tumor necrosis factor- $\alpha$.

\section{J. Clin. Invest.}

(c) The American Society for Clinical Investigation, Inc.

0021-9738/90/01/0185/07 \$2.00

Volume 85, January 1990, 185-191 induces the expression of the MHC class II genes, with a resulting increase in the surface expression of class II antigens (3). A number of biological and clinically important molecules are expressed by activated macrophages and yet the complex interactions involved in this activation process are still poorly understoód. Since certain activators can affect the maturation and differentiation of monocytes/macrophages, it is of interest to explore if such changes can affect the response of monocytes/macrophages to specific stimuli. Two important modulators of monocytes/macrophages, IFN- $\gamma$ or $1 \alpha, 25$-dihydroxyvitamin $D_{3}\left(1,25[O H]_{2} D_{3}\right)(4,5)$, were chosen to study possible effects on the pattern of subsequent activation of IL-1 and TNF genes in response to endotoxin.

Interleukin- $1 \alpha$ and $\beta$ and TNF- $\alpha$ are pleiotrophic macrophage products that share a large number of biological properties ranging from the induction of fever to the activation of $T$ lymphocytes $(6,7)$. Both IL-1 and TNF are induced in monocytes/macrophages or in the monocytic cell line THP1 by LPS or endotoxin, and this induction process is known to involve the activation of the relevant genes $(8,9)$. The induction of the IL-1 gene in THP1 cells in particular has been studied in detail, and it was shown that LPS activates IL- $1 \beta$ gene transcription very rapidly and only in a transient fashion (10). The existence of a repressor of IL-1 gene transcription, responsible for the remarkably short duration of the transcription process, has been postulated.

We had observed earlier that preincubation of the monocytic cell line U937 with IFN- $\gamma$ affects the response of these cells with respect to IL-1, $\mathrm{PGE}_{2}$, and superoxide production (11). We have now analyzed the expression of IL-1 and TNF genes in these cells in detail and observed that preincubation of cells with either IFN- $\gamma$ or $1,25(\mathrm{OH})_{2} \mathrm{D}_{3}$ potentiates the effect of LPS on the induction of IL-1 and TNF genes.

More importantly, cells pretreated with IFN- $\gamma$ for an extended period of time $(72 \mathrm{~h})$, exhibit a drastically different pattern of IL-1 gene activation by LPS, with a sustained increase in IL- $1 \alpha$ and $\beta$ gene expression, in contrast to the short pulse of IL-1 expression observed in control cells. Interestingly, a similar preincubation of U937 cells in the presence of $1,25(\mathrm{OH})_{2} \mathrm{D}_{3}$ does not alter the kinetics of IL-1 gene response to LPS, indicating distinct effects of IFN- $\gamma$ and $1,25(\mathrm{OH})_{2} \mathrm{D}_{3}$ on the mechanism of IL-1 gene regulation in monocytes/macrophages.

\section{Methods}

Cell culture. U937 cells (a monocytic cell line derived from an histiocytic lymphoma [12]) were maintained as suspension cultures in complete RPMI 1640 medium (Gibco Laboratories, Grand Island, NY) supplemented with $10 \%$ FCS (Gibco Laboratories), $2 \mathrm{mM}$ glutamine, $100 \mathrm{U} / \mathrm{ml}$ penicillin, and $100 \mu \mathrm{g} / \mathrm{ml}$ streptomycin. Cultures were incubated at $37^{\circ} \mathrm{C}$ in a humidified atmosphere containing $5 \% \mathrm{CO}_{2}$. Several sublines of U937 cells were obtained from different laboratories and found to exhibit different patterns of response to LPS, including no 
induction of IL-1 mRNA. A U937 line showing the best induction of IL-1 mRNA by LPS was chosen for further studies.

Reagents. LPS derived from Escherichia coli 055:B5 (Difco Laboratories, Inc., Detroit, MI) was prepared in sterile calcium and magnesium-free PBS and used at $20 \mu \mathrm{g} / \mathrm{ml}$. Phorbol myristate acetate (PMA), (Sigma Chemical Co., St. Louis, MO) was dissolved in DMSO to a concentration of $2 \mathrm{mg} / \mathrm{ml}$, stored at $-70^{\circ} \mathrm{C}$, and used at $5 \mathrm{ng} / \mathrm{ml}$. Recombinant human IFN- $\gamma$ at a specific activity of $21 \times 10^{6} \mathrm{U} / \mathrm{ml}$ (gift from Biogen Inc., Cambridge, MA) was used at $500 \mathrm{U} / \mathrm{ml}$. $1,25(\mathrm{OH})_{2} \mathrm{D}_{3}$, a gift from Hoffmann-La Roche Inc., Basel, was stored at $-20^{\circ} \mathrm{C}$ in ethanol and used at $4 \mathrm{ng} / \mathrm{ml}(10 \mathrm{nM})$.

Cell stimulation. U937 cells were cultured at $0.5 \times 10^{6}$ cells $/ \mathrm{ml}$ in 100 -mm-diam tissue culture dishes. IFN- $\gamma(500 \mathrm{U} / \mathrm{ml})$ or $1,25(\mathrm{OH})_{2} \mathrm{D}_{3}(4 \mathrm{ng} / \mathrm{ml}=10 \mathrm{nM})$ were added to the cell culture for 24 or $72 \mathrm{~h}$. The cells were then washed in PBS and stimulated in fresh medium with LPS $(20 \mu \mathrm{g} / \mathrm{ml})$ or PMA $(5 \mathrm{ng} / \mathrm{ml})$ for the time indicated.

$R N A$ preparation. Total RNA from $5 \times 10^{6}$ stimulated and control U937 cells was extracted by the guanidine isothiocyanate method as described (13) and purified by cesium chloride density gradient centrifugation.

$R N A$ analysis. For Northern blot analysis, 10- $\mu$ g samples of total guanidine-CsCl-purified RNA were denatured with glyoxal (14), fractionated on $1.4 \%$ agarose gel, and transferred to Biodyne A nylon membranes (Pall Corp., Glen Cove, NY). Blots were prehybridized for $4 \mathrm{~h}$ and hybridized with ${ }^{32} \mathrm{P}$-labeled RNA probes (15) for 16-20 $\mathrm{h}$ at $60^{\circ} \mathrm{C}$ in $50 \%$ formamide, $50 \mathrm{mM}$ Pipes (pH 6.8), $0.8 \mathrm{M} \mathrm{NaCl}, 2 \mathrm{mM}$ EDTA, $0.1 \%$ SDS, $2.5 \times$ Denhardt's solution, $100 \mu \mathrm{g} / \mathrm{ml}$ sonicated denatured herring sperm DNA, $1 \mathrm{mg} / \mathrm{ml}$ yeast RNA. Final washes of filters were done at high stringency $\left(0.2 \times \mathrm{SSC}\right.$, at $\left.78^{\circ} \mathrm{C}\right)$ for IL- $1 \beta$ and TNF- $\alpha$, and at lower stringency $\left(1 \times \mathrm{SSC}\right.$, at $\left.75^{\circ} \mathrm{C}\right)$ for IL- $1 \alpha$. Blots were exposed to XAR-5 films (Eastman Kodak Co., Rochester, NY) at $-70^{\circ} \mathrm{C}$ with intensifying screens.

DNA probes. DNA clones used in these experiments were pSP64 subclones of IL- $1 \alpha$, IL- $1 \beta$, and TNF- $\alpha$ cDNAs. For IL- $1 \alpha$, the internal 1,150-bp Sca I-Eco RI fragment of a human cDNA clone (16) was subcloned into the Sma I-Eco RI sites of pSP64. For IL-1 $\beta$, the internal 960-bp Pst I-Hpa II fragment of a human cDNA clone (17) was subcloned into the Pst I-Sma I sites of pSP64. For TNF- $\alpha$, the internal 980-bp Pst I-Hind III fragment of a human cDNA clone (generous gift from W. Fiers, University of Ghent, Belgium [18]) was subcloned into the Pst I-Hind III sites of pSP64. Plasmid pSP64 DNA and pSP64 subclone of $\alpha$ actin cDNA (19) were used as controls in nuclear transcription assay.

Nuclear transcription assay. The nuclear transcription assay was performed essentially as described (20). After stimulation, U937 cells $\left(10^{8}\right)$ were lysed for $10 \mathrm{~min}$ at $0^{\circ} \mathrm{C}$ in buffer $\mathrm{A}(60 \mathrm{mM} \mathrm{KCl}, 15 \mathrm{mM}$ $\mathrm{NaCl}, 0.15 \mathrm{mM}$ spermine, $0.5 \mathrm{mM}$ spermidine, $15 \mathrm{mM}$ Hepes [pH 7.5 ], $14 \mathrm{mM}$ beta-mercaptoethanol) containing $0.5 \%$ of NP-40. The homogenate was layered over a $10-\mathrm{ml}$ cushion of $30 \%$ sucrose in buffer $A$ and nuclei were pelleted for $10 \mathrm{~min}$ at $3,000 \mathrm{rpm}, 4^{\circ} \mathrm{C}$, in a rotor (Model HB4; Sorvall Instruments Co., Norwalk, CT). The nuclei were resuspended in nuclei storage buffer ( $20 \mathrm{mM}$ Tris- $\mathrm{HCl}$ [pH 8], $75 \mathrm{mM}$ $\mathrm{NaCl}, 0.5 \mathrm{mM}$ EDTA, $0.85 \mathrm{mM}$ DTT, $0.125 \mathrm{mM}$ PMSF, 50\% (vol/ vol) glycerol), sedimented for $2 \mathrm{~min}$ at $4^{\circ} \mathrm{C}$, and resuspended in nuclei storage buffer at $\sim 2 \times 10^{5}$ nuclei/ $\mu$ l. Nuclei were stored at $-70^{\circ} \mathrm{C}$ for several weeks without loss of activity. For the in vitro elongation reaction, $\sim 1-2 \times 10^{7}$ nuclei were incubated for $10 \mathrm{~min}$ at $26^{\circ} \mathrm{C}$ in $100 \mu \mathrm{l}$ of $100 \mathrm{mM}$ Tris- $\mathrm{HCl}(\mathrm{pH} 8), 50 \mathrm{mM} \mathrm{NaCl}, 0.4 \mathrm{mM}$ EDTA, $0.1 \mathrm{mM}$ PMFS, $1.2 \mathrm{mM}$ DTT, $350 \mathrm{mM}\left(\mathrm{NH}_{4}\right)_{2} \mathrm{SO}_{4}, 1 \mathrm{mg} / \mathrm{ml}$ heparine sulfate, $4 \mathrm{mM} \mathrm{MnCl} 2,2.5 \mu \mathrm{M}\left[\alpha_{-}{ }^{32} \mathrm{P}\right] \mathrm{UTP}, 400 \mathrm{Ci} / \mathrm{mmol}, 1 \mathrm{mM}$ each of GTP, ATP, and CTP, $29 \%$ glycerol, $10 \mathrm{mM}$ creatine phosphate, $100 \mu \mathrm{g} / \mathrm{ml}$ creatine kinase, and $400 \mathrm{U} / \mathrm{ml}$ ribonuclease inhibitor (Promega Biotec, Madison, WI). Labeled RNA was extracted from the mixture reaction as follows. The reaction was terminated by an incubation at $80^{\circ} \mathrm{C}$ for 3 min. $100 \mu \mathrm{g}$ of yeast RNA was then added and the sample was treated at $26^{\circ} \mathrm{C}$ for $10 \mathrm{~min}$ with $250 \mathrm{U} / \mathrm{ml}$ of RNase-free deoxyribonuclease I. The reaction was deproteinated by incubation at $42^{\circ} \mathrm{C}$ for $30 \mathrm{~min}$ in $1 \% \mathrm{SDS}, 5 \mathrm{mM}$ EDTA, $10 \mathrm{mM}$ Tris- $\mathrm{HCl}(\mathrm{pH} \mathrm{7.5),} 150 \mu \mathrm{g} / \mathrm{ml}$ of proteinase $\mathrm{K}$ and by subsequent phenol-chloroform extractions. RNA was precipitated twice with $2 \mathrm{M} \mathrm{NH}_{4}$ acetate and $1.5 \mathrm{vol}$ of ethanol for $5 \mathrm{~min}$ at $0^{\circ} \mathrm{C}$ to eliminate the nucleotide contaminants. The ${ }^{32} \mathrm{P}$-labeled RNA was denatured $2 \mathrm{~min}$ at $100^{\circ} \mathrm{C}$ and then hybridized to 1.5 $\mu \mathrm{g}$ of each denatured DNA sample that were applied to nitrocellulose filters (No. BA85; Schleicher \& Schuell, Inc., Keene, NH) and baked for $2 \mathrm{~h}$ at $80^{\circ} \mathrm{C}$. The filters were prehybridized for $48 \mathrm{~h}$, and hybridized with $15 \times 10^{6} \mathrm{cpm} / \mathrm{ml}$ of in vitro elongated RNA for $2 \mathrm{~d}$ at $42^{\circ} \mathrm{C}$ in $50 \%$ formamide, $50 \mathrm{mM} \mathrm{NaPO}_{4}(\mathrm{pH} 7), 0.75 \mathrm{M} \mathrm{NaCl}, 0.5 \%$ SDS, 2 mM EDTA, 10 $\times$ Denhardt's solution ( $1 \times$ Denhardt's solution $=0.02 \%$ BSA, $0.02 \%$ Ficoll, $0.02 \%$ polyvinylpyrrolidone), and 100 $\mu \mathrm{g} / \mathrm{ml}$ of sonicated denatured salmon sperm DNA. After hybridization, filters were washed $10 \mathrm{~min}$ at $37^{\circ} \mathrm{C}$ in $2 \times \mathrm{SSC}, 50 \mathrm{mM} \mathrm{NaPO}_{4}$ (pH 7), $0.5 \% \mathrm{SDS}, 1 \mathrm{~h}$ at $65^{\circ} \mathrm{C}$ in $0.1 \times \mathrm{SSC}, 50 \mathrm{mM} \mathrm{NaPO}{ }_{4}(\mathrm{pH} 7)$, $0.5 \% \mathrm{SDS}, 10 \mathrm{~min}$ at room temperature in $2 \times \mathrm{SSC}, 50 \mathrm{mM}$ Tris-HCl (pH 7), $0.1 \%$ SDS, and then treated for $10 \mathrm{~min}$ at $37^{\circ} \mathrm{C}$ with RNase $\mathrm{A}$. Blots were dried and exposed to Kodak XAR-5 films at $-70^{\circ} \mathrm{C}$ with intensifying screens.

\section{Results}

Effect of IFN- $\gamma$ and $1,25(\mathrm{OH})_{2} D_{3}$ on LPS or PMAinduced IL-1 and TNF- $\alpha$ gene expression

Effect of IFN- $\gamma$ preincubation on the activation of IL-1 and $T N F$ genes in $U 937$ cells. It was observed initially that several lines of U937, obtained from different laboratories, exhibited slightly different properties, for instance with respect to induction of HLA class II by IFN- $\gamma$ or induction of IL-1 by LPS. While one such line showed no IL-1 response to LPS, as has been reported by others $(21,22)$, other lines responded to LPS, as judged by IL-1 bioassays and mRNA. One such line of U937 cells was used for all experiments, and its responsiveness to LPS was documented in detail. Fig. 1 shows that LPS alone induces IL-1 mRNA, and Fig. $2 A$ shows the kinetic of the response with a maximum level at 3-4 $\mathrm{h}$ and subsequent decline. Preincubation with either medium alone (C), IFN- $\gamma$, or $1,25(\mathrm{OH})_{2} \mathrm{D}_{3}$, without subsequent activation by LPS $(-)$, does not induce IL-1 mRNA (Fig. $1 A$, lanes $1-3$ ). We observed only a slight effect of IFN- $\gamma$ on TNF- $\alpha$ mRNA (Fig. $1 B$, lanes 1 and 2). Hybridization to RNA of large size (mainly 28S) is nonspecific as frequently observed with SP6 probes. Treatment of U937 cells with LPS induces IL- $1 \alpha$ and $\beta$ mRNA, as well as TNF- $\alpha$ mRNA (Fig. 1, $A$ and $B$, and Fig. $2 A$ ).

Since it was observed earlier that preexposure of U937 to IFN- $\gamma$ modified the response of these cells (11), we analyzed the effect of preincubation of U937 cells with IFN- $\gamma$ on the subsequent induction of IL-1 by LPS. As shown in Fig. $1 \mathrm{~A}$, one observes a strong increase in the IL-1 mRNA response to LPS compared with cells not preincubated with IFN- $\gamma$. A similar potentiation of the effect of LPS was seen in the case of IL-1 $\alpha$ mRNA (data not shown) and TNF mRNA (Fig. $1 B$ ). We can therefore conclude that exposure of U937 cells to IFN- $\gamma$ has rendered them considerably more responsive to the LPS stimulatory signal.

PMA is also capable of inducing IL-1 and TNF genes. Again, preincubation of the cells with IFN- $\gamma$ resulted in an increase in the IL-1 $\beta$ mRNA response to PMA stimulation (Fig. $1 A$ ). Interestingly, this potentiation of the effect of PMA is not seen in the case of the TNF response, where one observes instead a reduction of TNF mRNA in cells preincubated with IFN- $\gamma$ (Fig. 1 B).

Preincubation with $1,25(\mathrm{OH})_{2}$ vitamin $\mathrm{D}_{3}$ also potentiates the induction of IL-1 by LPS. U937 cells were also preincubated with $1,25(\mathrm{OH})_{2} \mathrm{D}_{3}$ and tested for their response to LPS 

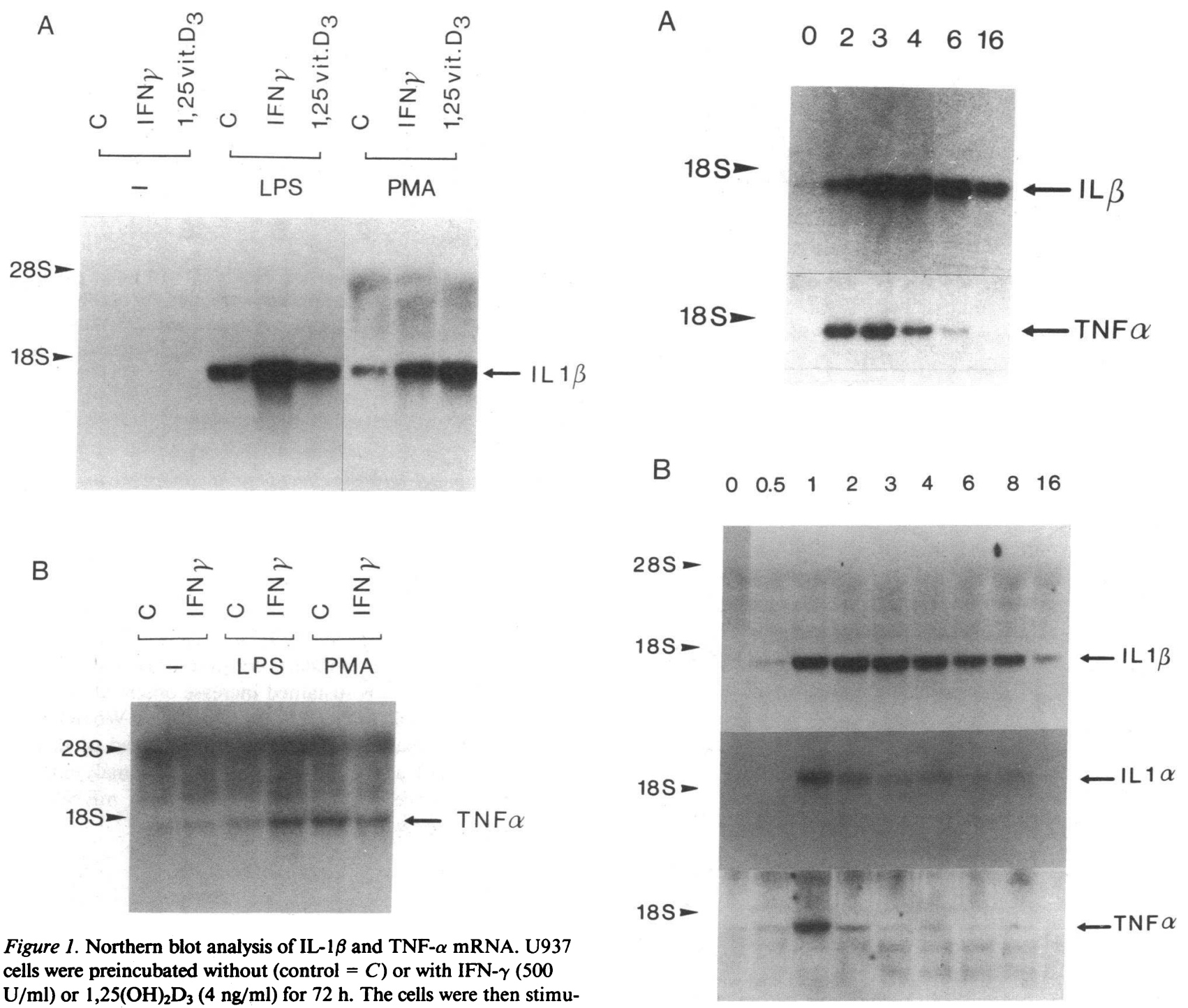

Figure 1. Northern blot analysis of IL-1 $\beta$ and TNF- $\alpha$ mRNA. U937 cells were preincubated without (control $=C)$ or with IFN- $\gamma(500$ $\mathrm{U} / \mathrm{ml})$ or $1,25(\mathrm{OH})_{2} \mathrm{D}_{3}(4 \mathrm{ng} / \mathrm{ml})$ for $72 \mathrm{~h}$. The cells were then stimulated without (-) or with LPS $(20 \mu \mathrm{g} / \mathrm{ml})$ or PMA $(5 \mathrm{ng} / \mathrm{ml})$ for $18 \mathrm{~h}$. $10 \mu \mathrm{g}$ of total RNA was analyzed by Northern blot hybridization. The filters were hybridized with IL-1 $\beta(A)$ or TNF- $\alpha(B)$ riboprobes.

or to PMA. As seen in Fig. $1 A$, one observes under these conditions a slight potentiation of the LPS response and a very large increase of the PMA response. It can thus be concluded that, as in the case of IFN- $\gamma$ preincubation, exposure of U937 cells to $1,25(\mathrm{OH})_{2} \mathrm{D}_{3}$ also modifies their responsiveness to subsequent activation signals.

Effect of IFN- $\gamma$ and $1,25(\mathrm{OH})_{2} \mathrm{D}_{3}$ on the kinetics of IL-1 and $T N F$ - $\alpha$ gene expression in response to LPS

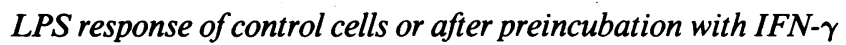
for $24 \mathrm{~h}$. In order to study in more detail this effect of IFN- $\gamma$ on the responsiveness of the monocytic cell line to LPS, we have carried out a kinetic study of the induction of the different genes involved under various conditions of prestimulation. Control cells responded to LPS with a short burst of IL-1 or TNF mRNA, with a maximum around $3 \mathrm{~h}$ (Fig. $2 \mathrm{~A}$ ). As mentioned above, this response concerns the particular U937 line used in this study, while other such lines are unresponsive to LPS (21). In the case of another monocytic cell line, THP1, it has been well documented that the short duration of the

Figure 2. Kinetics of IL- $1 \alpha$, IL- $1 \beta$, and TNF- $\alpha$ mRNA expression in control cells or after prestimulation for $24 \mathrm{~h}$. (A) U937 cells were stimulated by LPS $(20 \mu \mathrm{g} / \mathrm{ml})$ for $0,2,3,4,6$, and $16 \mathrm{~h}$. Northern blot analysis: $10 \mu \mathrm{g}$ of total RNA were hybridized with ${ }^{32} \mathrm{P}-\mathrm{cDNA}$ probes labeled by random priming for IL- $1 \beta$ and TNF- $\alpha$ mRNA. (B) U937 cells were incubated with IFN- $\gamma(500 \mu \mathrm{g} / \mathrm{ml})$ for $24 \mathrm{~h}$ and then stimulated by LPS $(20 \mu \mathrm{g} / \mathrm{ml})$ for $0,0.5,1,2,3,4,6,8$, and $16 \mathrm{~h} .10$ $\mu \mathrm{g}$ of total RNA were analyzed by Northern blot and hybridized with RNA probes for IL- $1 \alpha$, IL- $1 \beta$, and TNF- $\alpha$ mRNA. Experiments in Fig. 1 and Fig. 2, $A$ and $B$ used probes with different specific activity.

mRNA response reflects a transient activation of transcription together with a fairly short half-life of the mRNAs (10). After preincubation of U937 cells with IFN- $\gamma$ for 24 h (Fig. 2 B), there was no significant change in the kinetic of the mRNA response for IL- $1 \alpha$, IL- $1 \beta$, or TNF- $\alpha$, and again the level of all three mRNAs declined after $2-4 \mathrm{~h}$ after the beginning of LPS stimulation.

Preexposure to IFN- $\gamma$ for $72 \mathrm{~h}$ modifies the pattern of IL-I gene expression in response to LPS. When preincubation of U937 cells with IFN- $\gamma$ was carried out for a longer period (72 h), the response to LPS was drastically different (Fig. 3). For both IL- $1 \alpha$ and IL- $1 \beta$, the level of specific mRNA increased 

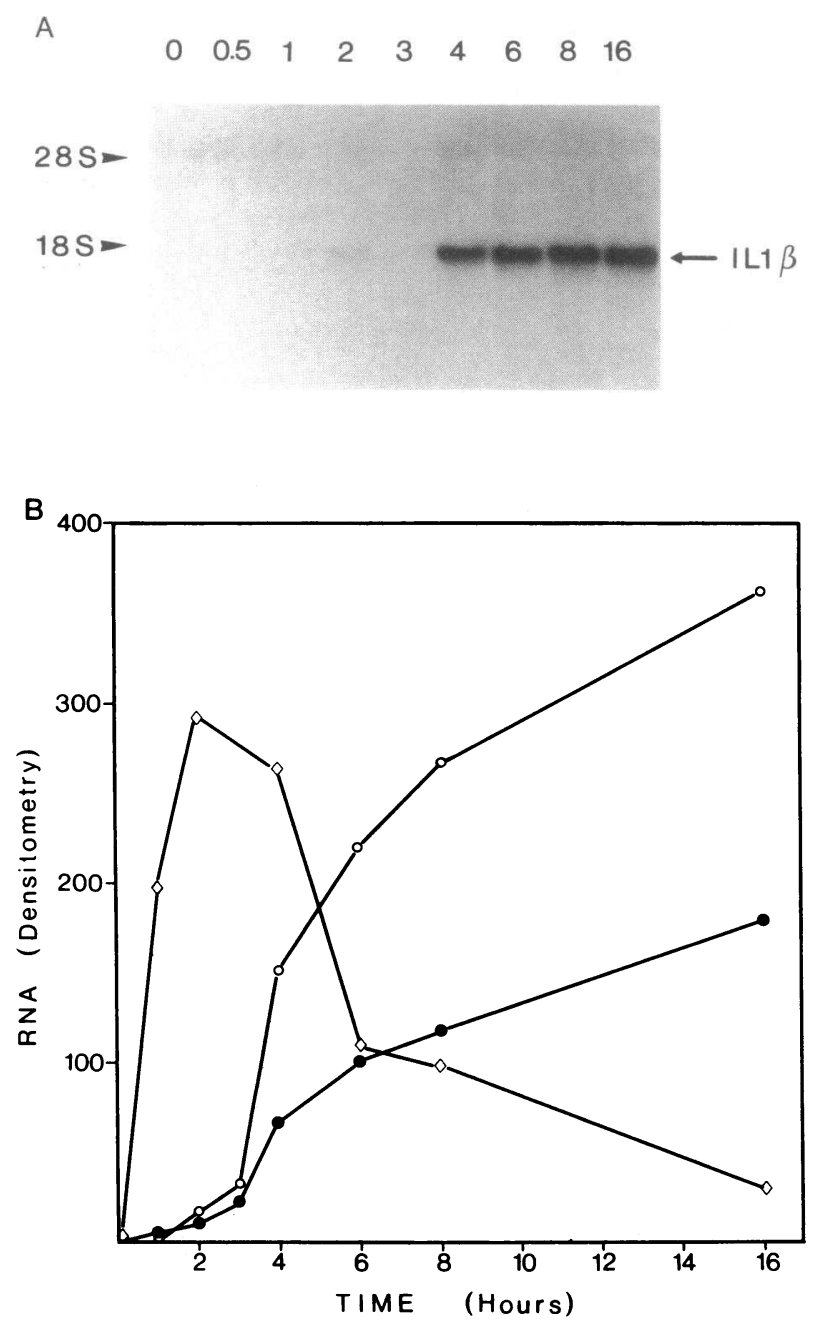

Figure 3. Kinetics of IL- $1 \alpha$, IL-1 $\beta$, and TNF- $\alpha$ mRNA expression after preincubation for $72 \mathrm{~h}$. U937 cells were incubated with IFN- $\gamma$ $(500 \mathrm{U} / \mathrm{ml})$ for $72 \mathrm{~h}$ and then stimulated by LPS $(20 \mu \mathrm{g} / \mathrm{ml})$ for 0 , $0.5,1,2,3,4,6,8$, and $16 \mathrm{~h}$. (A) Northern blot analysis of total RNA ( $10 \mu \mathrm{g} /$ lane) hybridized with riboprobe for IL-1 $\beta$ (Northern blot for IL- $1 \alpha$ and TNF- $\alpha$ not shown). (B) Densitometric representation scanning of autoradiographic films for IL-1 $\alpha(\bullet), \operatorname{IL}-1 \beta(0)$, and TNF- $\alpha(\diamond)$ mRNA.

gradually around 2-3 $\mathrm{h}$ after the addition of LPS and more importantly, the level of newly made IL-1 mRNA was maintained at a high level for as long as $16 \mathrm{~h}$ (Fig. 3). This unusual and sustained pattern of IL-1 gene activation in response to LPS was observed on several independent experiments and after $72 \mathrm{~h}$ of preexposure to IFN- $\gamma$.

To explore further this effect of IFN- $\gamma$ on the prolonged IL- 1 mRNA response to LPS, we analyzed the state of IL- $1 \alpha$ and $\beta$ gene transcription under these conditions by run-off experiments. As seen in Fig. 4, cells pretreated with IFN- $\gamma$ for $72 \mathrm{~h}$ responded to LPS with continuous transcription of the IL- $1 \alpha$ and $\beta$ genes.

Contrary to what was observed with IL-1 genes, the same prolonged preincubation with IFN- $\gamma$ had much less effect on the kinetics of appearance of TNF mRNA (Fig. 3, open dia$m o n d)$. Thus, IFN- $\gamma$ had modified the pattern of response of the IL- $1 \alpha$ and IL- $1 \beta$ genes to LPS without altering the response of the TNF gene.

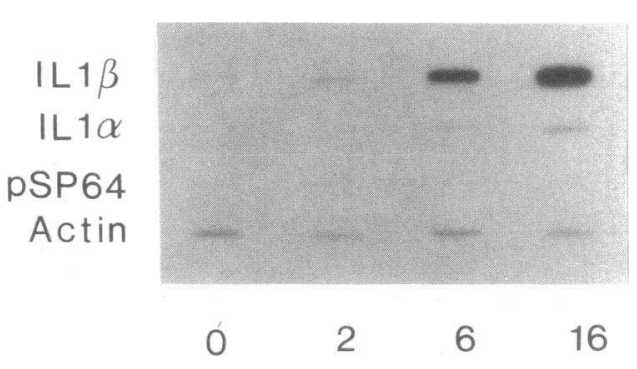

Figure 4. Nuclear transcription assays. Nuclei $\left(2 \times 10^{7}\right)$ were prepared from U937 cells cultured for $72 \mathrm{~h}$ in the presence of IFN- $\gamma$, then stimulated with LPS for $0,2,6$, and $16 \mathrm{~h}$. Purified ${ }^{32} \mathrm{P}$-labeled transcribed RNA were hybridized to $1.5 \mu \mathrm{g}$ of dot-blotted subclones of IL- $1 \beta$, IL- $1 \alpha$, and $\alpha$ actin cDNAs. pSP64 plasmid DNA was used as negative control.

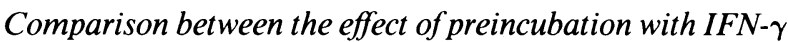
or $1,25(\mathrm{OH})_{2} \mathrm{D}_{3}$ on the kinetics of $\mathrm{IL}-1$ gene activation. Fig. 5 summarizes the time course of IL- 1 and TNF mRNA response to LPS after preincubation with either IFN- $\gamma$ or $1,25(\mathrm{OH})_{2} \mathrm{D}_{3}$. In all three panels, cells were preincubated for either $24 \mathrm{~h}$ (open circles) or $72 \mathrm{~h}$ (closed circles). The kinetics of IL-1 gene expression is drastically affected by IFN- $\gamma$ (panel $A$ ), and Fig. 4 has shown that this pattern reflects continuous IL-1 gene transcription. Curiously, this sustained increase observed for IL-1 mRNA does not apply to the TNF gene (panel $B$ ). When U937 cells were preincubated with $1,25(\mathrm{OH})_{2} \mathrm{D}_{3}$ instead of IFN- $\gamma$ and the kinetic of activation of the IL-1 gene analyzed, no significant difference was seen in the pattern of mRNA expression compared with control cells (panel $C$ ).

\section{Discussion}

The kinetics of IL-1 gene expression in response to LPS are modified by prior exposure to IFN- $\gamma$. LPS is a physiological inducer of the transcription of both IL-1 and TNF genes, and this process is characteristically of short duration in monocytes/macrophages. In the monocyte cell line THP1, one observes shortly after induction by LPS a repression of transcription of the IL-1 gene, and it was suggested that this "clamping" effect is the result of a transcriptional repressor factor (10). This rapid repression of IL- 1 gene expression results in a burst of IL-1 mRNA and a burst of IL-1 in response to LPS (10). A number of other genes have also been shown to be activated transcriptionally in a transient manner with evidence for short-lived repressor molecules (23-25).

Although U937 cells were described as being unresponsive to LPS with respect to IL1 genes $(21,22)$, we have identified sublines of U937 that do respond to LPS. With such a line, the induction of IL-1 mRNA by LPS is also transient with a maximum around 3-4 h (Fig. $2 A$ ). These differences may reflect the state of differentiation of different sublines of U937 after a very large number of generations.

The second conclusion from the work reported here is that the LPS-induced activation of both IL-1 and TNF genes can be potentiated by prior incubation of U937 cells in the presence of either IFN- $\gamma$ or $1,25(\mathrm{OH})_{2} \mathrm{D}_{3}$. We observed that control cells, as well as cells incubated with IFN- $\gamma$ for only $24 \mathrm{~h}$, responded to LPS with a transient burst of IL-1 expression (Fig. 2, $A$ and $B$ ). 

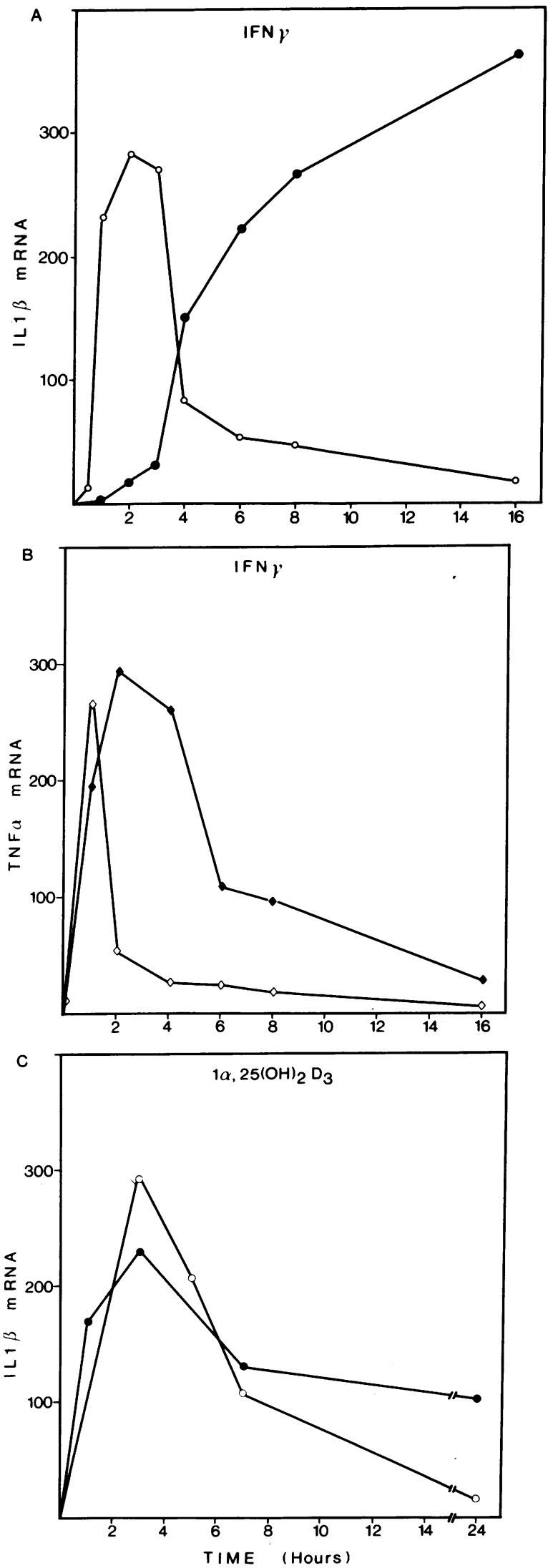

Figure 5. Comparison of preincubation of U937 cells with IFN- $\gamma$ or $1,25(\mathrm{OH})_{2} \mathrm{D}_{3}$. Cells were preincubated with IFN- $\gamma(A$ and $B)$ and $1,25(\mathrm{OH})_{2} \mathrm{D}_{3}(C)$. Preincubation time was $24 \mathrm{~h},(\mathrm{O})$ or $72 \mathrm{~h},(\bullet)$. The mRNA analyzed were IL-1 $\beta(A$ and $C$ ) and TNF- $\alpha(B)$.
More importantly, preexposure of U937 cells to IFN- $\gamma$ for $72 \mathrm{~h}$ modifies these cells in such a fashion that they now respond to LPS differently. Instead of the short burst of IL-1 gene expression, one observes in these cells a prolonged increase in IL-1 gene transcription with a gradual accumulation of IL-1 mRNA, at least up to $16 \mathrm{~h}$. This surprisingly different pattern of IL-1 gene response indicates that prolonged exposure of the U937 cells to IFN- $\gamma$ has modified the mechanism of IL-1 gene regulation by LPS. In particular, the transcriptional repressor that is thought to control IL-1 gene expression may be no longer operative. This change in the program of IL-1 gene response to LPS induced by IFN- $\gamma$ can either reflect a change in the differentiation state of U937 cells or an indirect effect of secreted factors acting in an autocrine fashion during the 72-h preincubation period. The pattern of regulation of IL- $1 \alpha$ and $\beta$ genes has been markedly modified by this preincubation, contrary to what is observed with the TNF- $\alpha$ gene, indicating subtle differences in the mechanisms of regulation of IL-1 and TNF genes. As observed earlier in monocytes (26), IL- $1 \beta$ mRNA was always much more abundant than IL- $1 \alpha$ mRNA in U937 cells, but both were affected in the kinetics of expression after the preincubation with IFN- $\gamma$. Preliminary experiments on THP1 cells have a similar modification of the IL-1 genes in response to LPS after prolonged exposure to IFN- $\gamma$, this indicating that in both monocyte lines, the differentiation by IFN- $\gamma$ has led to a change in the pattern of regulation of IL-1 genes. The effect of the preincubation on the stimulation of IL-1 genes by PMA has not been investigated further. It is interesting, however, that PMA was shown to induce a sustained IL- $1 \beta$ mRNA response in another monocyte cell line (THP1), suggesting again the existence of different patterns of regulation for IL-1 genes (21).

It is tempting to speculate on the possible physiological consequences of this drastic change of the time course of IL-1 gene expression. One of the numerous effects of endotoxin in vivo is the activation of IL-1 and TNF genes. On the basis of the in vitro data, it is likely that this activation process is normally short-lived. Whenever and wherever a local production of IFN- $\gamma$ may take place such as in the case of viral infection, one can expect on the basis of the results presented here, that monocytes will now respond to LPS in vivo with a sustained production of IL-1. A prolonged IL-1 response to LPS would have obvious pathophysiological consequences.

Effects of IFN- $\gamma$ and $1,25(\mathrm{OH})_{2} \mathrm{D}_{3}$ on human monocytes/ macrophages. IFN- $\gamma$, which is a major macrophage-activating factor, enhances oxidative metabolism and antimicrobial activity of monocytes as well as tumoricidal activity $(1,2)$. IFN- $\gamma$ also enhances the expression of MHC class II antigens on monocytes (27). Although IFN- $\gamma$ by itself does not induce IL-1 secretion by human monocytes, it greatly enhances IL-1 secretion when monocytes were simultaneously or subsequently stimulated by LPS or Staphylococcus aureus $(28,29)$. The mechanism of this enhanced secretion of IL-1 is not known. In the U937 cell line, IFN- $\gamma$ inhibits cell proliferation (30), stimulates antibody-dependent cellular cytotoxicity and the expression of Fc receptors (31), and induces the ability to generate a respiratory burst (32). IFN- $\gamma$ alone does not induce IL-1 production by $\mathrm{U} 937$ cells (33).

$1,25(\mathrm{OH})_{2} \mathrm{D}_{3}$, which is the active metabolite of vitamin $\mathrm{D}_{3}$ and is well known as a regulator of calcium homeostasis and bone metabolism in man (34), is also recognized as an immunomodulatory hormone (35). $1,25(\mathrm{OH})_{2} \mathrm{D}_{3}$ is involved in 
myeloid differentiation and affects monocyte/macrophage functions. Like IFN- $\gamma, 1,25(\mathrm{OH})_{2} \mathrm{D}_{3}$ activates the oxidative metabolism (36) and increases IL-1 production (37) of freshly isolated human monocytes. Like IFN- $\gamma, 1,25(\mathrm{OH})_{2} \mathrm{D}_{3}$ also inhibits cell proliferation, increases Fc-receptor expression and antibody-dependent cellular cytotoxicity of U937 cells (38), and enhances the competence of these cells to produce oxygen metabolites (11). 1,25(OH) ${ }_{2} \mathrm{D}_{3}$ increases IL-1 production, not alone but in association with a factor expressed by human $\mathrm{T}$ lymphocytes (39). In contrast to these similarities, $1,25(\mathrm{OH})_{2} \mathrm{D}_{3}$ differs from IFN- $\gamma$ in its capacity to alter cellular response to $\mathrm{PGE}_{2} .1,25(\mathrm{OH})_{2} \mathrm{D}_{3}$, but not IFN- $\gamma$, decreased the cellular content of adenosine CAMP and shifted the dose-response curve in response to $\mathrm{PGE}_{2}$ in U937 cells (40). In contrast to IFN- $\gamma, 1,25(\mathrm{OH})_{2} \mathrm{D}_{3}$ lowered HLA-DR expression on human peripheral blood monocytes (41).

In view of the striking similarities of the effects of IFN- $\gamma$ and $1,25(\mathrm{OH})_{2} \mathrm{D}_{3}$ on monocytes/macrophages, the observation of a unique effect of IFN- $\gamma$ on the regulation of IL- 1 gene expression in response to LPS is of interest. Somehow, the maturation or differentiation steps induced in monocytes by IFN- $\gamma$ or by $1,25(\mathrm{OH})_{2} \mathrm{D}_{3}$ must differ. Only IFN- $\gamma$ is capable of modifying the program of IL-1 gene regulation in a way that permits a prolonged expression of IL-1 genes in response to endotoxin.

\section{Acknowledgments}

We thank M. Zufferey and C. Modoux for their excellent technical assistance and L. Kedes for the actin cDNA probe.

This work was supported by the Swiss National Fund for Scientific Research: grant 3.360-0.86 (Dr. B. Mach) and 3.400-0.86 (Dr. J.-M. Dayer) and Subvention Fédérale Suisse pour la lutte contre le rhumatisme (Dr. Dayer).

\section{References}

1. Adams, D. O., and T. A. Hamilton. 1984. The cell biology of macrophage activation. Annu. Rev. Immunol. 2:283-318.

2. Johnston, R. B. 1988. Monocytes and macrophages. N. Engl. J. Med. 118:747-752.

3. Unanue, E. R. and P. M. Allen. 1987. The basis for the immunoregulatory role of macrophages and other accessory cells. Science (Wash. DC). 236:551-557.

4. Adams, D. O., and T. A. Hamilton. 1987. Molecular transductional mechanisms by which IFN $\gamma$ and other signals regulate macrophage development. Immunol. Rev. 97:5-27.

5. Amento, E. P. 1987. Vitamin D and the immune system. Steroids. 49:55-72.

6. Dinarello, C. A. 1986. Multiple biological properties of recombinant human Interleukin 1 (beta). Immunobiology. 172:301-315.

7. Beutler, B., and A. Cerami. 1986. Cachectin and tumor necrosis factor as two sides of the same biological coin. Nature (Lond.). 320:584-588.

8. Auron, P. E., and A. C. Webb. 1987. Molecular biology of interleukin 1. Lymphokines. 14:33-61.

9. Cerami, A., and B. Beutler. 1988. The role of cachectin/TNF in endotoxic shock and cachexia. Immunol. Today. 9:28-31.

10. Fenton, M. J., B. D. Clark, K. L. Collins, A. C. Webb, A. Rich, and P. E. Auron. 1987. Transcriptional regulation of the human prointerleukin $1 \beta$ gene. J. Immunol. 138:3972-3979.

11. Roux-Lombard, P., A. Cruchaud, and J.-M. Dayer. 1986. Effect of interferon- $\gamma$ and $1 \alpha, 25$-dihydroxyvitamin $D_{3}$ on superoxide anion, prostaglandins E2, and mononuclear cell factor production by U937 cells. Cell. Immunol. 97:286-296.
12. Sundström, C., and K. Nilsson. 1976. Establishment and characterization of a human histiocytic lymphoma cell line (U937). Int. J. Cancer. 17:565-577.

13. Chirgwin, J. M., A. E. Przybyla, R. J. MacDonald, and W. J. Rutter. 1979. Isolation of biologically active ribonucleic acid from sources enriched in ribonuclease. Biochemistry. 18:5294-5299.

14. McMaster, G. K., and G. G. Carmichael. 1977. Analysis of single- and double-stranded nucleic acids on polyacrylamide and agarose gels by using glyoxal and acridine orange. Proc. Natl. Acad. Sci. USA. 74:4835-4838.

15. Melton, D. A., P. A. Krieg, M. R. Rebagliati, T. Maniatis, K. Zinn, and M. R. Green. 1984. Efficient in vitro synthesis of biologically active mRNA and RNA hybridization probes from plasmids containing a bacteriophage SP6 promoter. Nucleic Acids Res. 12:7035-7056.

16. Wingfield, P., M. Payton, P. Graber, K. Rose, J.-M. Dayer, A. R. Shaw, and U. Schmeissner. 1987. Purification and characterization of human interleukin-1 $\alpha$ produced in Escherichia coli. Eur. J. Biochem. 165:537-541.

17. Wingfield, P., M. Payton, J. Tavernier, M. Barnes, A. Shaw, K Rose, M. G. Simona, S. Demczuk, K. Williamson, and J.-M. Dayer. 1986. Purification and characterization of human interleukin- $1 \beta$ expressed in recombinant Escherichia coli. Eur. J. Biochem. 160:491497.

18. Marmenout, A., L. Fransen, J. Tavernier, J. Van Der Heyden, R. Tizard, E. Kawashima, A. Shaw, M.-J. Johnson, D. Semon, R. Müller, M.-R. Ruysschaert, A. Van Vliet, and W. Fiers. 1985. Molecular cloning and expression of human tumor necrosis factor and comparison with mouse tumor necrosis factor. Eur. J. Biochem. 152:515522.

19. Gunning, P., P. Ponte, H. Okayama, J. Engel, H. Blau, and L. Kedes. 1983. Isolation and characterization of full-length cDNA clones for human $\alpha-, \beta$-, $\gamma$-actin mRNAs: skeletal but not cytoplasmic actins have an amino-terminal cysteine that is subsequently removed. Mol. Cell. Biol. 3:787-795.

20. Schibler, U., O. Hagenbuchle, P. K. Wellauer, and A. C. Pittet. 1983. Two promoters of different strengths control the transcription of the mouse alpha-amylase gene amy-la in the parotid gland and the liver. Cell. 33:501-508.

21. Fenton, M. J., M. W. Vermeulen, B. D. Clark, A. C. Webb, and P. E. Auron. 1988. Human pro-IL-1 $\beta$ gene expression in monocytic cells is regulated by two distinct pathways. J. Immunol. 140:22672273.

22. Lachman, L. B., J. O. Moore, and R. S. Metzgar. 1978. Preparation and characterization of lymphocyte-activating factor (LAF) from acute monocytic and myelomonocytic leukemia cells. Cell. Immunol. 41:199-206.

23. Collart, M. A., D. Belin, J.-D. Vassalli, S. de Kossodo, and P. Vassalli. 1986. $\gamma$ Interferon enhances macrophage transcription of the tumor necrosis factor/cachectin, interleukin 1, and urokinase genes, which are controlled by short-lived repressors. J. Exp. Med. 164:2113-2118.

24. Raj, N. B. K., and P. M. Pitha. 1983. Two levels of regulation of $\beta$-interferon gene expression in human cells. Proc. Natl. Acad. Sci. USA. 80:3923-3927.

25. Mitchell, R. L., L. Zokas, R. D. Schreiber, and I. M. Verma 1985. Rapid induction of the expression of proto-oncogene fos during human monocytic differentiation. Cell. 40:209-217.

26. Demczuk, S., C. Baumberger, B. Mach, and J. M. Dayer. 1987. Expression of human IL $1 \alpha$ and $\beta$ messager RNAs and IL 1 activity in human peripheral blood mononuclear cells. J. Mol. Cell. Immunol. 3:255-265.

27. Sztein, M. B., P. S. Steeg, H. M. Johnson, and J. J. Oppenheim. 1984. Regulation of human peripheral blood monocyte DR antigen expression in vitro by lymphokines and recombinant interferon. $J$. Clin. Invest. 73:556-565.

28. Gerrard, T. L., J. P. Siegel, D. R. Dyer, and K. C. Zoon. 1987. 
Differential effects of interferon- $\alpha$ and interferon- $\gamma$ on interleukin 1 secretion by monocytes. J. Immunol. 138:2535-2540.

29. Arenzana-Seisdedos, F., J. L. Virelizier, and W. Fiers. 1985 Interferons as macrophage-activating factors. III. Preferential effects of interferon- $\gamma$ on the interleukin 1 secretory potential of fresh or aged human monocytes. J. Immunol. 134:2444-2448.

30. Larrick, J. W., D. G. Fischer, S. J. Anderson, and H. S. Koren. 1980. Characterization of a human macrophage-like cell line stimulated in vitro: a model of macrophage functions. J. Immunol. 125:612.

31. Shen, L., P. M. Guyre, and M. Fanger. 1983. Direct stimulation of ADCC by cloned interferon gamma is not ablated by glucocorticoids studies using a human monocyte-like cell line (U937). Mol. Immunol. 21:167-173.

32. Clement, L. T., and J. E. Lehmeyer. 1983. Regulation of the growth and differentiation of a human monocytic cell line by lymphokines. 1. Induction of superoxide anion production and chemiluminescence. J. Immunol. 130:2763-2766.

33. Amento, E. P., J. T. Kurnick, and S. M. Krane. 1985. Interleukin 1 production by the human monocyte cell line U937 requires a lymphokine induction signal distinct from interleukin 2 or interferons. J. Immunol. 134:350-357.

34. De Luca, H. F., and H. K. Schnoes. 1983. Vitamin D: recent advances. Annu. Rev. Biochem. 52:411-439.

35. Rigby, W. F. C. 1988. The immunobiology of vitamin D. Immunol. Today. 9:54-58.
36. Cohen, M. S., D. E. Mesler, R. G. Snipes, and T. K. Gray. 1986 1,25-dihydroxyvitamin $D_{3}$ activates secretion of hydrogen peroxyde by human monocytes. J. Immunol. 136:1049-1053.

37. Bhalla, A. K., E. P. Amento, and S. M. Krane. 1986. Differential effect of 1,25-dihydroxyvitamin $D_{3}$ on human lymphocytes and monocyte/macrophages: inhibition of interleukin- 2 and augmentation of interleukin-1 production. Cell. Immunol. 98:311-322.

38. Rigby, W. F. C., L. Shen, E. L. Ball, P. M. Guyre, and M. W. Fanger. 1984. Differentiation of a human monocytic cell line by 1,25 dihydroxyvitamin $D_{3}$ (calcitriol): a morphologic, phenotypic and functional analysis. Blood. 64:1110-1115.

39. Amento, E. P., A. K. Bhalla, J. T. Kurnick, R. L. Kradin, T. L. Clemens, S. A. Holick, M. F. Holick, and S. M. Krane. 1984. $1 \alpha$,25dihydroxyvitamin $D_{3}$ induces maturation of the human monocyte cell line U937 and, in association with a factor from T lymphocytes, augments the production of the monokine, mononuclear cell factor. $J$. Clin. Invest. 73:731-739.

40. Goldring, S. R., E. P. Amento, M. S. Roelke, and S. M. Krane. 1986. The adenosine $3^{\prime}, 5^{\prime}$ cyclic monophosphate response to prostaglandin E2 is altered in U937 cells in association with maturational events induced by activated $\mathrm{T}$ lymphocytes and 1,25-dihydroxyvitamin $D_{3}$. J. Immunol. 136:3461-3466.

41. Amento, E. P., M. U. Suddard, A. K. Bhalla, and S. M. Krane. 1986. 1,25-dihydroxyvitamin $D_{3}$ and interferon $\gamma$ have opposing effects on HLA-DR and Leu M-3 expression by monocytes/macrophages. Arthritis Rheum. 29:S86. (Abstr.) 